\title{
GASEOUS EMISSIONS FROM FOSSIL FUELS AND BIOMASS COMBUSTION IN SMALL HEATING APPLIANCES
}

\author{
Daniele Dell'Antonia, Rino Gubiani, Daniele Maroncelli, Gianfranco Pergher
}

\section{Introduction}

Energy resources will play an important role in the world's future. Energy is considered a prime agent in the generation of wealth and a significant factor in economic development. The importance of energy in economic development is recognized universally and historical data confirm that there is a strong relationship between the availability of energy and economic activity. There are many alternative new and renewable energy sources which can be used as a substitute for fossil and conventional fuels [Demirbas 2005]. Biomass such as wood, bark, straw, and biowaste is a promising $\mathrm{CO}_{2}$-neutral alternative solid fuel owing to the decreasing resources of fossil fuels [Zhou 2006].

Current energy consumption of biomass accounts for about $14 \%$ of total world energy consumption, second only to coal, oil, and natural gas. Developing countries account for $75 \%$ of the biomass utilization [Zhao 2008]. As to 2008, the energy consumption in Italy was 192.1 Mtoe (million tons of oil equivalent), where all renewable energy resources, including hydropower and biomass, accounted for 15.9 Mtoe (about 8.3\%) [ENEA 2008]. While no official figures exist as to the contribution of biomass alone, some recent estimates report a total potential of 24-30 Mtoe (about 13.6\%) [Report 2008 ITABIA].

For biomass utilization it is more important to assess the economic feasibility relative to non-renewable energy, especially for industrial processes which may obtain the fossil fuel at a lower price than ordinary consumers. For this reason, recently it was suggested to use agricultural products such as corn for domestic heating. The possibility to use corn for combustion arises from the severe limitations on the maximum aflatoxin and fumonisin content of alimentary

Paper received 21.12.2009; accepted 19.08.2010

Prof. Gianfranco Pergher Full Professor (pergher@uniud.it), Prof Rino Gubiani, Associate Professor (rino.gubiani@uniud.it), Dr Daniele Dell'Antonia, PhD Student (daniele.dellantonia@uniud.it), Dr DANiele Maroncelli, Grant Research (daniele.maroncelli@uniud. it). Department of Agricultural and Environmental Sciences (DiSA), University of Udine, Via delle Scienze, 208, loc. Rizzi, Udine, Italy. corn set by EU regulations [Reg. CE 1881/2006 and Reg. CE 1126/2007] In fact, Italian corn production often exceeds such limits. In Friuli Venezia Giulia, corn production, as well as the storage, moving and handling of grain corn has evolved to a point where there are very few unknowns. Every year farmers harvest, dry, convey, and store about one million tons of corn in Friuli Venezia Giulia. The equipment to do all these things is readily available. Moreover, the opportunity of using corn and barley residues of drying as a fuel allows the agricultural production to be diversified towards the energetic compartment.

Residential combustion of biofuel may be carried out in simple wood stoves as well as in more advanced ones, such as pellet burners and modern wood boilers, and the emissions of pollutants may vary over a wide range [Johansson, 2004]. The importance of emission control has increased sharply due to the increased need of energy from combustion. However, biomass utilization in energy production is not free from problems because of physical and chemical characteristics which are substantially different from conventional energy sources [Ahmed Khana, 2008]. Thermal utilisation of solid biofuels is influenced by the kind of solid biofuel used, its physical characteristics (e.g. particle size, bulk density, moisture content, gross calorific value (GCV)) and its chemical composition [Obernberger, 2006]. It is known that the biomass burning in boilers emit pollutants in the atmosphere, the main of which are particulates, carbon monoxide (CO), unburned hydrocarbons ( $\mathrm{CxHy}$ ) and nitrogen oxides (NOx). As pointed out by Smith 1994, the products of incomplete combustion have three major adverse effects: energy loss, impact on human health and impact on the environment. He estimated that the use of biomass fuels contributed 1 to $5 \%$ of all $\mathrm{CH}_{4}$ emissions, 6 to $14 \%$ of all $\mathrm{CO}$ emissions, 8 to $24 \%$ of all total non-methane organic compounds (TNMOC) emissions and thus 1 to $3 \%$ of all human induced global warming [Bhattacharya 2000].

For an assessment of biomass as an energy source, from the environmental point of view, it would be important to establish the magnitude of different emissions from the present energy use of biomass. If no 
significant changes occur in end-use biomass energy technologies, emission would be expected to be proportional to the total biomass energy use in the future. Also, corrective measures/interventions may be necessary if the emissions are found to be unacceptably high [Bhattacharya 2000]. For this reason the study was aimed at the report of gaseous products namely $\mathrm{CO}_{2}$, $\mathrm{CO}, \mathrm{NOx}, \mathrm{SO}_{2}$, and hydrocarbons computing emission factors for various compositions of corn biomass, compared to fossil fuel combustions (natural gas, LPG and diesel boiler) in a small residential boiler.

\section{Materials and methods}

Tests were carried out in Friuli Venezia Giulia in 2006-2008 to assess the emissions of the main pullutant gases $\left(\mathrm{CO}, \mathrm{NO}, \mathrm{NO}_{2}, \mathrm{NOx}, \mathrm{SO}_{2}\right.$ and $\left.\mathrm{CO}_{2}\right)$ from twenty residential heating appliances (Tab. 1), using six different fossil or biomass fuels (Tab. 2). In total twenty-seven tests were carried out.

The boilers of fossil fuel present a very short period of start-stop, conversely to the biofuel boilers that take a long time to take a regime. For this reason the biomass plant included a buffer, whose function is a termic accumulation, to reduce the start-stop of the plant and thus improve the performance of the boiler with significant reductions of the emissions (Tab. 2).

The flue gas emission was measured with a professional semi-continuous multi-gas analyzer, (Vario plus industrial, MRU air Neckarsulm-Obereisesheim). Emissions of $\mathrm{CO}_{2}, \mathrm{CO}$ and unburnt hydrocarbons (expressed as $\mathrm{CH}_{4}$ ) were measured with an infrared bench, while $\mathrm{O}_{2}, \mathrm{NO}, \mathrm{NO}_{2}$ and $\mathrm{SO}_{2}$ were measured electrochemically with a sensor with three electrodes. The NOx gas was determined from a sum of NO and $\mathrm{NO}_{2}$.

For all tested boilers, the same methodology was performed. Initially, the boiler was turned on and when it started to work continuously, the emissions were recorded for a period of 60 minutes. The instrument probe was introduced in the center of the flue, in a direction perpendicular to the smoke. All measurements were performed at specific points of the chimney stack, distant at least four times the diameter of the flue, in order to avoid any turbulence of the flow (Fig. 1). Fossil fuel boilers achieve full power within a few minutes, while the biomass boilersrequired at least 1 hour to obtain a constant maximum power. For the whole period of the analysis, all tests were performed at the maximum power of the boiler. The gas is sucked from the probe and analyzed by the instrument every one second.

This test did not include the measurement of the particulate matter, because the stretch of the chimneys was not sufficient to insert the probes. Indeed, the gravimetric method requires two more probes compared to the gas analysis, while the method for direct reading with the infrared system requires larger diameters.
The values were measured in parts per million (ppm, volume to volume). However, the Italian environmental law 152/2006 requires that the concentration of a pollutant in smoke be expressed as a mass per unit volume of the flue gas, under reference conditions. This is in order to avoid that the combustion smoke be diluted by adding air in excess. Therefore, the reference conditions fix some limits for the residual oxygen tenor in the flue gas, which are: $3 \%$ for liquid and gaseous fuels and $11 \%$ for biomass fuels.

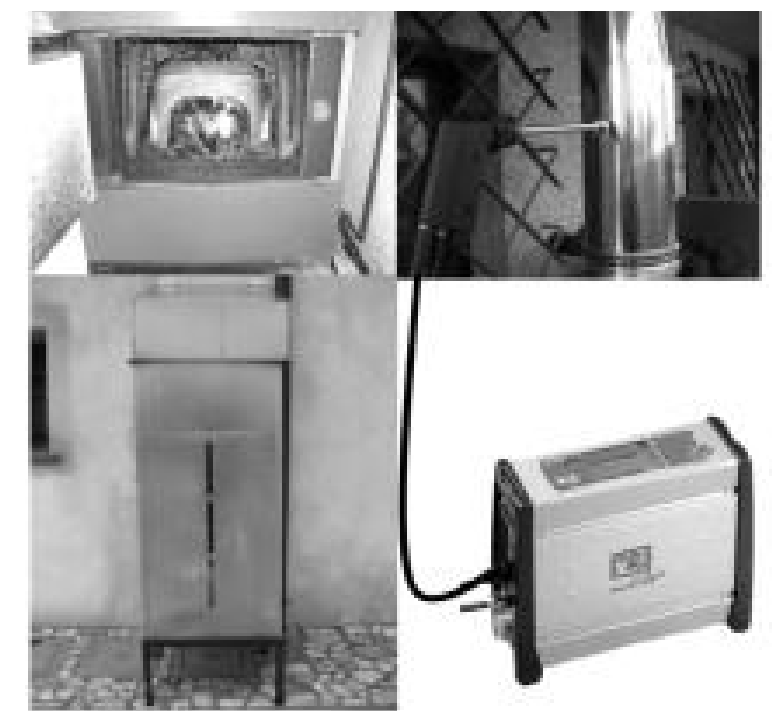

Fig. 1 - Chimney emissions analysis.

The following formula was used to calculate the mass to volume concentration:

$$
C_{\text {air }}-C_{w j y} \cdot \frac{F M}{22.4}
$$

where:

$C_{m / v}$, in $\mathrm{mg} / \mathrm{m}^{3}$, is the mass to volume concentration; $C_{v / v}$, in ppm, is the volume concentration;

$F M$, in $\mathrm{g} / \mathrm{kmol}$, is the formula weight;

22.4 , in $\mathrm{m}^{3} / \mathrm{kmol}$, is the specific volume of a gas at $20^{\circ} \mathrm{C}$ temperature and $101.325 \mathrm{kPa}$ (Avogadro's law).

The following formula was then used to adjust the concentration in accordance with the maximum oxygen percentage allowed in the flue:

$$
C_{r i c}=C_{* / v} \times \frac{21-O_{2} r}{21-O_{2} f}
$$

where:

$C_{r / c}$, in $\mathrm{mg} / \mathrm{m}^{3}$, is the mass to volume concentration in reference conditions (residual oxygen of $11 \%$ );

$C_{m / v}$, in $\mathrm{mg} / \mathrm{m}^{3}$, is the mass to volume concentration;

$\mathrm{O}_{2 r}$, is the reference oxygen $(11 \%)$;

$\mathrm{O}_{2 f}$, is the measured oxygen (\%).

Finally, flow emissions from corn combustion were determined using a Pitot tube to measure the fluid flow velocity. The basic Pitot tube simply consists of a tube pointing directly into the fluid flow. As this tube contains air, a pressure can be measured as the moving air. 


\begin{tabular}{|c|c|c|c|c|c|}
\hline \multirow{2}{*}{ Boiler } & Number of test & Fuel & Feeding Sistem & $\begin{array}{c}\text { Heat output } \\
(\mathrm{kW})\end{array}$ & $\begin{array}{c}\text { Buffer tank } \\
(\mathrm{l})\end{array}$ \\
\hline Corn A & 3 & Pellets and grain & Automatic & 25 & 700 \\
\hline Corn B & 2 & Pellets and grain & Automatic & 29 & NP \\
\hline Corn C & 2 & Pellets and grain & Automatic & 25 & 200 \\
\hline Barley A & 1 & Pellets and grain & Automatic & 20 & 500 \\
\hline Chips A & 1 & Chips, pellets and grain & Automatic & 50 & 500 \\
\hline Chips B & 1 & Chips, pellets and grain & Automatic & 30 & 200 \\
\hline Chips C & 1 & Chips & Automatic & 300 & 1000 \\
\hline Stove A & 2 & Log of wood & Manual & 11 & NP \\
\hline Stove B & 1 & Log of wood & Manual & 11 & NP \\
\hline Diesel (1) & 4 & Diesel & Automatic & $25-30$ & NP \\
\hline LPG (1) & 3 & LPG & Automatic & $25-30$ & NP \\
\hline Methane (1) & 6 & Methane & & NP \\
\hline \multicolumn{2}{|l|}{$\begin{array}{l}\text { (1) Technical data for boilers are the same for every type of fossili fuels } \\
\text { NP =The buffer tank is not present }\end{array}$} & & & \\
\hline
\end{tabular}

TABLE 1 - Technical data of biomass boilers.

\begin{tabular}{|c|c|c|c|c|c|c|c|c|}
\hline Parameter & Peck & $\begin{array}{l}\text { Natural } \\
\text { gas }\end{array}$ & $\begin{array}{l}\text { LPG } \\
(1)\end{array}$ & Diesel & $\begin{array}{c}\text { Wood chips } \\
\text { (2) }\end{array}$ & $\begin{array}{c}\text { Log wood } \\
\text { (2) }\end{array}$ & $\begin{array}{l}\text { Grain from } \\
\text { barley } \\
\text { (2) }\end{array}$ & $\begin{array}{l}\text { Grain from } \\
\text { corn }\end{array}$ \\
\hline Carbon - (C) & wt $\%$ (d.b.) & 75 & 82 & 85.3 & 50.8 & 48.8 & 45.1 & 45.74 \\
\hline Hydrogen - $(\mathrm{H})$ & wt $\%$ (d.b.) & 25 & 18 & 12.7 & 6.3 & 6.2 & 6.5 & 6.46 \\
\hline Sulphur - (S) & wt\% (d.b.) & - & - & 1 & 0.02 & 0.02 & 0.1 & 0.11 \\
\hline Nitrogen - (N) & wt\% (d.b.) & - & - & - & 0.1 & 0.1 & 2 & 1.6 \\
\hline Oxygen - $(\mathrm{O})$ & wt $\%$ (d.b.) & - & - & - & 41.9 & 43.9 & 44.1 & 44.49 \\
\hline Ash & wt $\%$ (d.b.) & - & - & - & 0.3 & 0.3 & 2 & 1.6 \\
\hline Moisture & wt $\%$ (w.b.) & - & - & - & 20 & 14 & 14 & 14 \\
\hline \multirow{2}{*}{$\mathrm{NCV}$} & $\mathrm{MJ} / \mathrm{kg}$ (d.b.) & 47.7 & 46 & 43.1 & 19.1 & 18.9 & 17.05 & 17.7 \\
\hline & $\mathrm{MJ} / \mathrm{kg}$ (w.b.) & 47.7 & 46 & 43.1 & 15.3 & 16.2 & 14.7 & 15.2 \\
\hline \multicolumn{9}{|c|}{$\begin{array}{l}\text { (1) The values of chemical analysis are referred to propane } \\
\text { (2) Source normative UNI CEN/TS } 14961 \\
\text { d.b.= Dry basis; w.b.= Wet basis }\end{array}$} \\
\hline
\end{tabular}

TABLE $\quad 2-$ Chemical analysis of fuel type.

\section{Results and discussion}

The estimated mean value of the selected gases/ pollutants obtained from combustion fuels, used for energy, is shown in Table 3. The whole process of thermal utilisation of fuels (fuel supply, combustion system, solid and gaseous emissions) is influenced by the kind of fuel used, its physical characteristics and its chemical composition. Moreover it was clear that the combustion conditions and the chamber design 
greatly affected the content of the flue gases, as results have proved. In the ideal case, combustion represents the complete oxidation of the fuel into the $\mathrm{CO}_{2}$ and $\mathrm{H}_{2} \mathrm{O}$ gases. For the biomass combustion, this conversion occurs in three steps: drying of the fuel (va- porising of water), pyrolysis/gasification (thermal degradation in the absence or presence of externally supplied oxygen, respectively) and the final oxidation of the charcoal and the flue gases [Obernberger 2006].

\begin{tabular}{|c|c|c|c|c|c|c|c|c|c|c|}
\hline Boiler & Test & $\begin{array}{c}\text { Oxygen } \\
\left(\mathrm{O}_{2}\right) \\
(\%)\end{array}$ & $\begin{array}{c}\text { Real } \\
\text { Carbon } \\
\text { dioxide } \\
\left(\mathrm{CO}_{2}\right) \\
(\%)\end{array}$ & $\begin{array}{c}\text { Carbon } \\
\text { dioxide } \\
\left(\mathrm{CO}_{2}\right) \\
(\%) \\
(1)\end{array}$ & $\begin{array}{c}\text { Carbon } \\
\text { monoxide } \\
(\mathrm{CO}) \\
\left(\mathrm{mg} / \mathrm{m}^{3}\right) \\
(1)\end{array}$ & $\begin{array}{c}\text { Nitrogen } \\
\text { monoxide } \\
(\mathrm{NO}) \\
\left(\mathrm{mg} / \mathrm{m}^{3}\right) \\
(1)\end{array}$ & $\begin{array}{c}\text { Nitrogen } \\
\text { dioxide } \\
\left(\mathrm{NO}_{2}\right) \\
\left(\mathrm{mg} / \mathrm{m}^{3}\right) \\
(1)\end{array}$ & $\begin{array}{c}\text { Nitrogen } \\
\text { oxides } \\
(\mathrm{NOx}) \\
\left(\mathrm{mg} / \mathrm{m}^{3}\right) \\
(1)\end{array}$ & $\begin{array}{c}\text { Sulphur } \\
\text { dioxide } \\
\left(\mathrm{SO}_{2}\right) \\
\left(\mathrm{mg} / \mathrm{m}^{3}\right) \\
(1)\end{array}$ & $\begin{array}{c}\text { Gas } \\
\text { temperature } \\
\left({ }^{\circ} \mathrm{C}\right)\end{array}$ \\
\hline Corn A & 1 & 16.4 & 4.3 & 9.2 & 1,310 & 263 & 83 & 486 & 147 & 193 \\
\hline Corn A & 2 & 13.9 & 6.6 & 9.4 & 1,026 & & & 402 & 175 & 277 \\
\hline Corn A & 3 & 17.3 & 3.4 & 9.0 & 588 & 407 & 48 & 672 & 130 & 171 \\
\hline Corn B & 4 & 15.7 & 4.9 & 9.2 & 234 & 424 & 41 & 692 & 103 & 203 \\
\hline Corn B & 5 & 18.6 & 2.1 & 8.8 & 1,240 & 302 & 219 & 682 & 108 & 170 \\
\hline Corn $\mathrm{C}$ & 6 & 8.4 & 11.7 & 9.2 & 41 & 461 & 8 & 715 & 85 & 105 \\
\hline Corn $\mathrm{C}$ & 7 & 11.3 & 9.2 & 9.5 & 293 & 432 & 39 & 702 & 124 & 227 \\
\hline Barley A & 8 & 19.3 & 1.6 & 9.2 & 727 & 376 & 93 & 669 & 166 & 145 \\
\hline Chips A & 9 & 13.0 & 7.6 & 9.3 & 4,652 & 286 & 3 & 443 & 0 & 159 \\
\hline Chips B & 10 & 9.3 & 11.3 & 9.7 & 335 & 278 & 3 & 429 & 0 & 208 \\
\hline Chips C & 11 & 7.0 & 12.9 & 9.2 & 73 & 119 & 2 & 185 & 5 & 93 \\
\hline Stove A & 12 & 18.1 & 2.7 & 9.2 & 8,397 & 0 & 69 & 68 & 50 & 155 \\
\hline Stove A & 13 & 16.1 & 4.7 & 9.6 & 7,806 & 146 & 5 & 229 & 0 & 374 \\
\hline Stove B & 14 & 13.0 & 7.8 & 9.7 & 3,546 & 62 & 58 & 153 & 2 & 352 \\
\hline Diesel A & 15 & 11.1 & 7.1 & 7.2 & 6 & 67 & 2 & 105 & 82 & 199 \\
\hline Diesel B & 16 & 4.8 & 11.6 & 7.2 & 9 & 83 & 2 & 130 & 97 & 161 \\
\hline Diesel C & 17 & 17.5 & 2.5 & 3.4 & 39 & 87 & 4 & 194 & 515 & 74 \\
\hline Diesel D & 18 & 12.7 & 6.0 & 7.2 & 4 & 63 & 2 & 99 & 91 & 124 \\
\hline LPG A & 19 & 8.7 & 8.1 & 6.6 & 5 & 76 & 17 & 135 & 0 & 113 \\
\hline LPG B & 20 & 12.8 & 5.5 & 6.6 & 43 & 73 & 25 & 163 & 0 & 116 \\
\hline LPG B & 21 & 12.7 & 5.2 & 6.3 & 45 & 85 & 30 & 287 & 0 & 113 \\
\hline Methane A & 22 & 15.1 & 3.3 & 5.4 & 39 & 88 & 29 & 163 & 0 & 49 \\
\hline Methane A & 23 & 17.1 & 2.1 & 4.8 & 65 & 55 & 25 & 110 & 0 & 100 \\
\hline Methane B & 24 & 6.8 & 7.9 & 5.6 & 15 & 20 & 7 & 38 & 0 & 212 \\
\hline Methane C & 25 & 3.6 & 9.5 & 5.5 & 13 & 31 & 11 & 58 & 0 & 61 \\
\hline Methane D & 26 & 18.0 & 1.6 & 6.6 & 62 & 101 & 41 & 203 & 5 & 91 \\
\hline Methane E & 27 & 16.1 & 1.9 & 3.6 & 59 & 62 & 21 & 116 & 0 & 85 \\
\hline
\end{tabular}

TABLE 3 - Total emissions of $\mathrm{O}_{2}, \mathrm{CO}_{2}, \mathrm{CO}, \mathrm{NO}, \mathrm{NO}_{2}, \mathrm{NOx}$ and $\mathrm{SO}_{2}$ in fuel combustion. 
After drying, the main controlling parameter of the combustion process is the ratio between the amount of air added and the amount of air (oxygen) necessary for a complete combustion of the combustible parts of the fuel (excess air). In reverse, an incomplete combustion can lead to emissions of unburnt carbon-based pollutants such as carbon monoxide, hydrocarbons, polycyclic aromatic hydrocarbons, tar and soot [Obernberger 2006]

\subsection{Carbon dioxide}

Carbon is the main component of solid biofuels and contributes positively to the gross calorific value (GCV). The Carbon contents of wood fuels are lightly higher than that of corn grain or another herbaceous biofuels, which explains the slightly higher GCV of wood fuels (Tab. 2). Therefore, carbon dioxide emissions from biomass combustion in comparison to the emissions of fossil fuels are $\mathrm{CO}_{2}$-neutral [Obernberger, 2006], because the carbon is absorbed by plants to produce the same amount of organic matter through the process of photosynthesis $\left(\mathrm{CO}_{2}\right.$ is a major product of complete combustion).

Figure 1 shows that a sum of the $\mathrm{CO}_{2}$ and $\mathrm{O}_{2}$ concentrations is $20 \%$ in corn combustion, which is similar for all types of biomass when used in a typical family boiler. The carbon dioxide in adjusting conditions of residual oxygen $(11 \%)$ in the flue gas, is shown in Table 3, where the data are the same with respect to the fuel type, although different combustion boilers are used.

\subsection{Carbon monoxide}

Carbon monoxide is usually produced when the combustion air is supplied at less than the stoichiomet- ric requirement. Firstly, during the primary attack by oxygen on hydrocarbons, $\mathrm{CO}$ is formed by a fast reaction mechanism shown in equation [1]. The subsequent reaction of $\mathrm{CO}$ to $\mathrm{CO}_{2}$ in equation [2] is slow and requires adequate residence time to achieve completion. Secondly, as the combustion proceeds through the fuel bed after the primary reaction, the oxygen is very much depleted and the carbon dioxide is reduced by the Boudouard reaction in the next layer of fuel [3] [Ndiema, 1998]. The Boudouard reaction is the redox reaction of a chemical equilibrium mixture of carbon monoxide and carbon dioxide at a given temperature. It is the disproportionation of carbon monoxide into carbon dioxide and graphite or its reverse.

$$
\begin{array}{ll}
\mathrm{C}+0.5 \mathrm{O}_{2} \rightarrow \mathrm{CO} & \text { (Exothermic) } \\
\mathrm{CO}+0.5 \mathrm{O}_{2} \rightarrow \mathrm{CO}_{2} & \text { (Endothermic) } \\
\mathrm{CO}_{2}+\mathrm{C} \rightarrow 2 \mathrm{CO} & \text { (Endothermic) }
\end{array}
$$

Thus, under suitable conditions of temperature and oxygen concentration, the combustion gases formed in the primary zone containing a high carbon dioxide concentration may equilibrate as the gases pass through the regions of unburnt fuel. The reduction reaction in equation [3] is endothermic and this will cause the gases to cool as the reaction proceeds. When the temperatures drop to the level where the rate of reaction becomes negligible, the equilibrium process will stop, and the concentration of $\mathrm{CO}$ will be frozen. It has been shown that this occurs in the temperature range of $600-700^{\circ} \mathrm{C}$ [Ndiema 1998].

Both the deficiency of air and excess air lead to an increase of the $\mathrm{CO}$ concentration. Probabily, high excess air can be suspected to cool the combustion chamber, resulting in high CO emissions [Johansson 2004].

\begin{tabular}{|c|c|c|c|c|c|c|c|c|c|c|}
\hline Fuels & $\begin{array}{c}\text { Analysis } \\
\text { number }\end{array}$ & $\begin{array}{c}\text { Oxygen } \\
\left(\mathrm{O}_{2}\right) \\
(\%)\end{array}$ & $\begin{array}{c}\text { Real } \\
\text { Carbon } \\
\text { dioxide } \\
\left(\mathrm{CO}_{2}\right) \\
(\%)\end{array}$ & $\begin{array}{c}\text { Carbon } \\
\text { dioxide } \\
\left(\mathrm{CO}_{2}\right) \\
(\%) \\
(1)\end{array}$ & $\begin{array}{c}\text { Carbon } \\
\text { monoxide } \\
(\mathrm{CO}) \\
\left(\mathrm{mg} / \mathrm{m}^{3}\right) \\
(1)\end{array}$ & $\begin{array}{c}\text { Nitrogen } \\
\text { monoxide } \\
(\mathrm{NO}) \\
\left(\mathrm{mg} / \mathrm{m}^{3}\right) \\
(1)\end{array}$ & $\begin{array}{c}\text { Nitrogen } \\
\text { dioxide } \\
\left(\mathrm{NO}_{2}\right) \\
\left(\mathrm{mg} / \mathrm{m}^{3}\right) \\
(1)\end{array}$ & $\begin{array}{c}\text { Nitrogen } \\
\text { oxides } \\
(\mathrm{NOx}) \\
\left(\mathrm{mg} / \mathrm{m}^{3}\right) \\
(1)\end{array}$ & $\begin{array}{c}\text { Sulphur } \\
\text { dioxide } \\
\left(\mathrm{SO}_{2}\right) \\
\left(\mathrm{mg} / \mathrm{m}^{3}\right) \\
(1)\end{array}$ & $\begin{array}{c}\text { Gas } \\
\text { temperature } \\
\left({ }^{\circ} \mathrm{C}\right)\end{array}$ \\
\hline Corn & 7 & 14 & 6 & 9 & 676 & 381 & 73 & 622 & 125 & 192 \\
\hline Barley & 1 & 19 & 2 & 9 & 727 & 376 & 93 & 669 & 166 & 145 \\
\hline Chips & 3 & 10 & 11 & 9 & 1,687 & 228 & 3 & 352 & 2 & 153 \\
\hline Stove & 3 & 16 & 5 & 9 & 6,583 & 69 & 44 & 150 & 17 & 294 \\
\hline Diesel & 4 & 12 & 7 & 6 & 15 & 75 & 3 & 132 & 196 & 140 \\
\hline LPG & 3 & 11 & 6 & 7 & 31 & 78 & 24 & 195 & 0 & 114 \\
\hline Methane & 6 & 13 & 4 & 5 & 42 & 60 & 22 & 115 & 1 & 100 \\
\hline
\end{tabular}

TABLE 4 - Total emissions of $\mathrm{O}_{2}, \mathrm{CO}_{2}, \mathrm{CO}, \mathrm{NO}, \mathrm{NO}_{2}, \mathrm{NOx}$ and $\mathrm{SO}_{2}$ in fuel combustion for each fuesl investigated. 
The testing confirms that in biomass combustion the high carbon monoxide emissions are clearly very high in comparison to fossil combustion because there is not a good mixing between fuel and air and sufficient retention time at high temperatures (Tab. 3-4). In the first and second analysis of the corn boiler A (1310 and $1026 \mathrm{mg} / \mathrm{m}^{3}$ ) the average value was higher than in the third analysis $\left(588 \mathrm{mg} / \mathrm{m}^{3}\right)$. This was most likely due to the replacement of the combustion grate that had deteriorated. In the chips boiler $\mathrm{C}$ emissions the value was $4652 \mathrm{mg} / \mathrm{m}^{3}$. This value was most likely due to the chips' moisture (40-50\%) used in the combustion. This situation was detected in slumber conditions [Bignal, 2008]. In the diesel boiler $C$, the emissions value (39 $\mathrm{mg} / \mathrm{m}^{3}$ ) was higher than other diesel heaters (4-9 $\mathrm{mg} / \mathrm{m}^{3}$ ), because the boiler was working discontinously for the presence of an underfloor heating system in the house. Indeed, the higher values in carbon monoxide emissions took place in the stages of ignition and shutdown of the plant. For the biomass combustion the worst situation was detected in the traditional stove combustion $\left(6583 \mathrm{mg} / \mathrm{m}^{3}\right)$, where the $\log$ of wood did

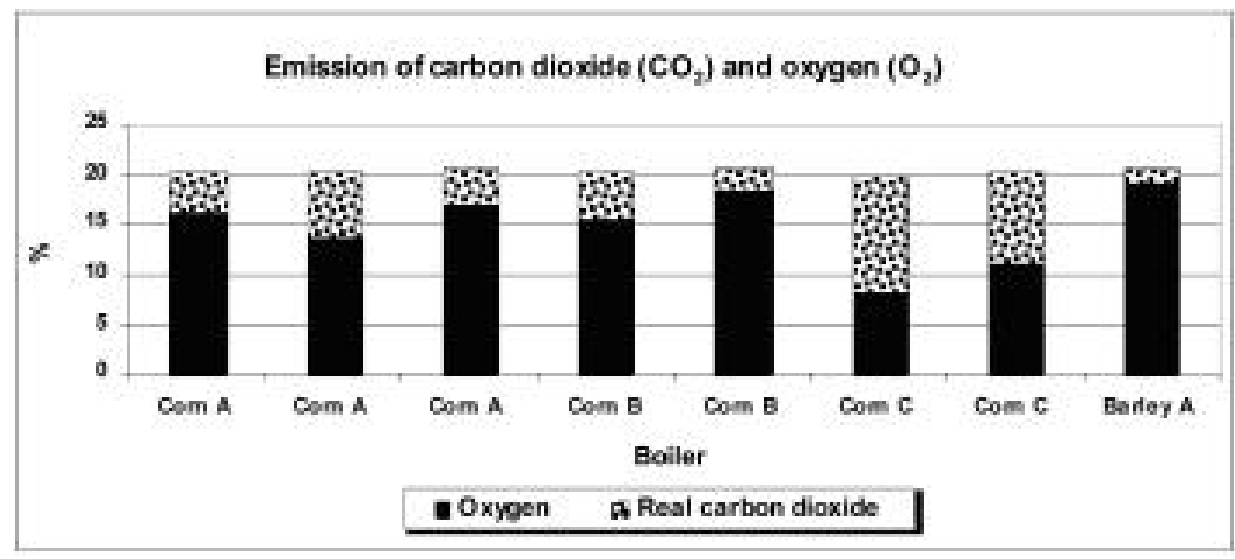

Fig. 2 - Real emissions of carbon dioxide $\left(\mathrm{CO}_{2}\right)$ and oxygen $\left(\mathrm{O}_{2}\right)$ in fuel combustion.

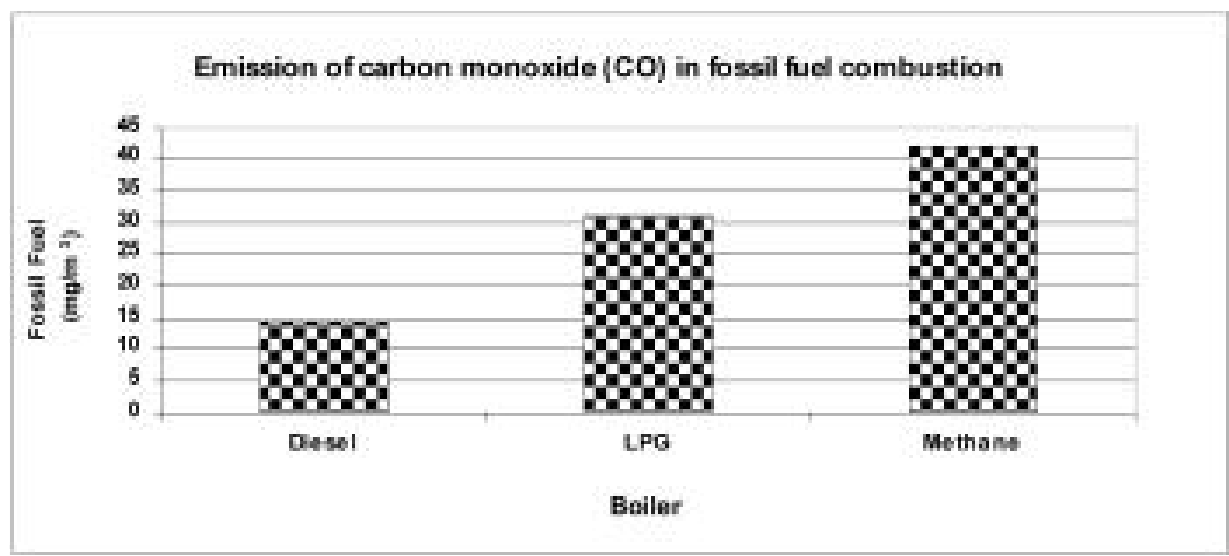

Fig. 3 - Emissions of carbon monoxide (CO) in fossil fuel combustion.

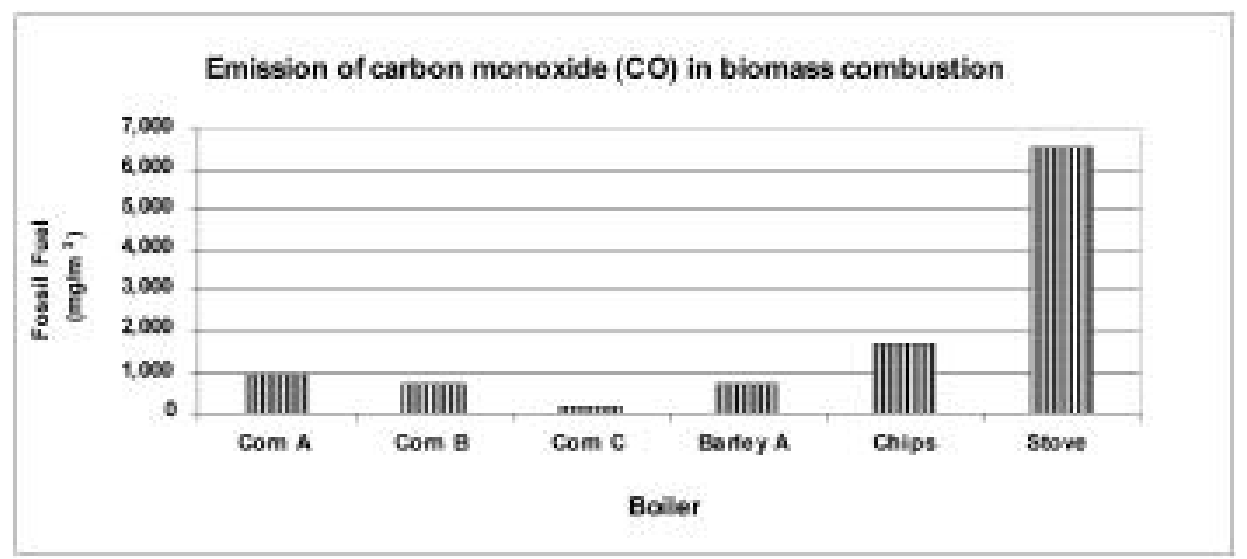

Fig. 4 - Emissions of carbon monoxide $(\mathrm{CO})$ in biomass combustion. 


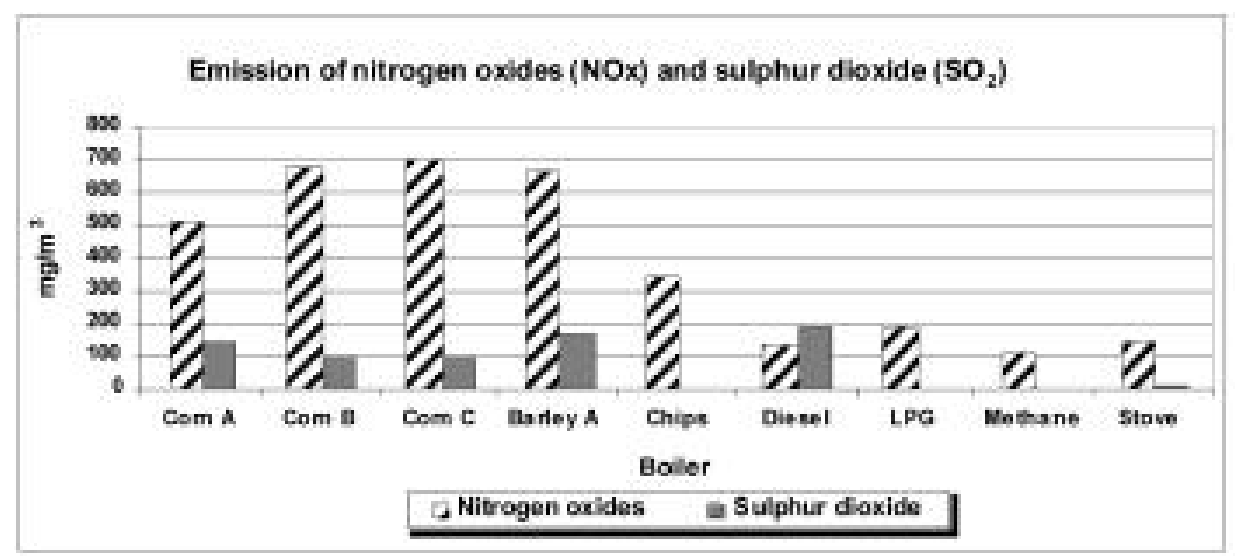

Fig. 5 - Emissions of nitrogen oxides $(\mathrm{NOx})$ and sulphur dioxide $\left(\mathrm{SO}_{2}\right)$ in fuel combustion.

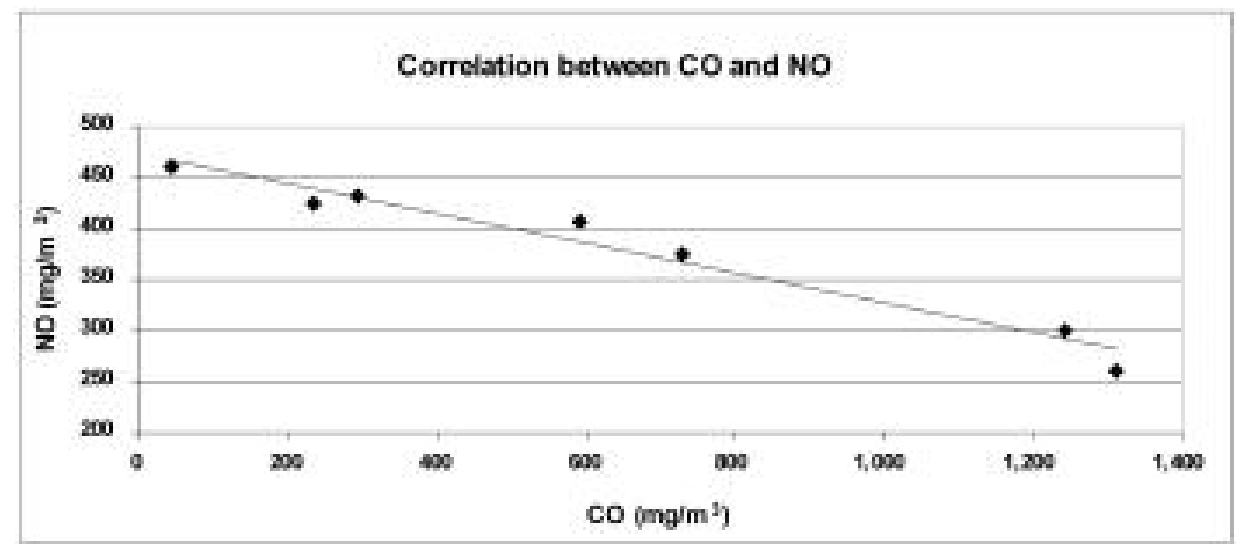

Fig. 6 - Correlation between carbon monoxide (CO) and nitrogen monoxide (NO) for corn and barley combustion.

not burn in a uniform way while lower emissions were detected in corn boiler C (167 mg/m³) (Fig. 4).

\subsection{Nitrogen oxides}

One of the main environmental impacts of solid biofuel combustion is caused by NOx emissions. The main mechanism of NOx formation in the fuel biomass, when the temperature of combustion is between $800-1200^{\circ} \mathrm{C}$, is the oxidation of the nitrogen contained in the fuel. The determining factors are the amount of fuel bound nitrogen in the ultimate analyses, the $\mathrm{O}_{2}$ concentration in the flame area and to a lesser degree its temperature. Conversely, main mechanisms of NOx in fossil fuels are thermal NOx (formed by the reaction of airborne $\mathrm{N}$ with oxygen radicals at temperatures above $1300^{\circ} \mathrm{C}$ ) and prompt NOx (formed by airborne $\mathrm{N}$ at temperatures above $1300^{\circ} \mathrm{C}$ under low oxygen conditions in the presence of hydrocarbons). The determining factor in this mechanisms is the maximum temperature in the combustion zone [Obernberger 2006; Teixeira 2004] In connection with these concepts, the higher the nitrogen content in the fuel, the higher the NOx emissions from the biomass combustion. Since the flame combustion in biomass is in the range of $800-1200^{\circ} \mathrm{C}$, the nitrogen in fuel is almost entirely converted to gaseous $\mathrm{N}_{2}$ and nitrogen oxides
( $\mathrm{NO}$ and $\mathrm{NO}_{2}$ ). Only an insignificant amount of $\mathrm{N}$ is incorporated in the ash.

According to Table 2, coniferous and deciduous wood have the lowest nitrogen content, while higher concentrations are found in grain from barley and corn. The date of emission confirms the higher percentage of nitrogen oxides in corn combustion in comparison to wood and fossil fuels (Fig. 5). The average emissions in the boiler that used grain corn is $622 \mathrm{mg} / \mathrm{m}^{3}$ in comparison to the $195 \mathrm{mg} / \mathrm{m}^{3}$ to $\mathrm{LPG}$ fuels (Tab. 3 and 4).

It can also be noted that for biomass boilers, the highest emissions of NOx compounds were obtained when the lowest unoxidized compounds concentrations were measured and reversibly, the lowest concentrations of NOx were correlated to the highest unoxidized compounds values [Johansson 2004]. Infact in figure 6 there is an inversecorrelation between carbon monoxide and nitrogen monoxide for corn and barley combustion. The nitrogen monoxide is the greater part of nitrogen oxides.

\subsection{Sulphur dioxide}

The sulphur contained in the solid biofuel forms mainly gaseous $\mathrm{SO}_{2}$. Due to the subsequent cooling of the flue gas in the boiler section of the combustion 


\begin{tabular}{|c|c|c|c|c|c|c|}
\hline \multirow{2}{*}{ Corn boiler } & \multirow{2}{*}{$\begin{array}{l}\text { Flow } \\
(1 / \mathrm{s})\end{array}$} & \multirow{2}{*}{$\begin{array}{c}\text { Oxygen }\left(\mathrm{O}_{2}\right) \\
(\%)\end{array}$} & \multicolumn{2}{|c|}{ Carbon monoxide (CO) } & \multicolumn{2}{|c|}{ Nitrogen oxides (NOx) } \\
\hline & & & $\mathrm{mg} / \mathrm{m}^{3}(1)$ & $\mathrm{mg} / \mathrm{h}$ & $\mathrm{mg} / \mathrm{m}^{3}(1)$ & $\mathrm{mg} / \mathrm{h}$ \\
\hline Corn $\mathrm{C}$ & 7 & 11.3 & 293 & 6,779 & 702 & 17,035 \\
\hline Corn A & 12 & 17.3 & 588 & 8,813 & 672 & 9,979 \\
\hline Corn B & 20 & 18.6 & 1,240 & 20,088 & 682 & 11,952 \\
\hline
\end{tabular}

TABLE 5 - Flow emissions of $\mathrm{O}_{2}, \mathrm{CO}$ and NOx in corn combustion boiler.

plant, SOx forms sulphates and condenses on the heat exchanger surfaces or reacts directly with fly ash particles deposited on heat exchanger surfaces (sulphation). The efficiency of sulphur fixation in the ash depends on the concentration of alkali and earth-alkali metals (especially $\mathrm{Ca}$ ) in the fuel (fuels like wood chips and bark can contain high $\mathrm{Ca}$ contents and therefore cause a high S fixation) [Obernberger 2006].

The average emission of sulphur dioxide in corn biomass combustion is $125 \mathrm{mg} / \mathrm{m}^{3}$ while wood emis- sions are smaller $\left(2 \mathrm{mg} / \mathrm{m}^{3}\right.$ for chip combustion and $17 \mathrm{mg} / \mathrm{m}^{3}$ for stove combustion) because this biomass contains a low percentage of sulphur in comparison to the corn biomass (Tab. 3 and 4). The emission of diesel combustion in table 4 is high $\left(196 \mathrm{mg} / \mathrm{m}^{3}\right)$ because the diesel boiler $\mathrm{C}\left(515 \mathrm{mg} / \mathrm{m}^{3}\right)$ was working discontinously for the presence of an underfloor heating system in the house. Emissions of $\mathrm{SO}_{2}$ in the LPG and methane boiler are instead lacking because these fuels do not contain sulphur (Fig. 5).

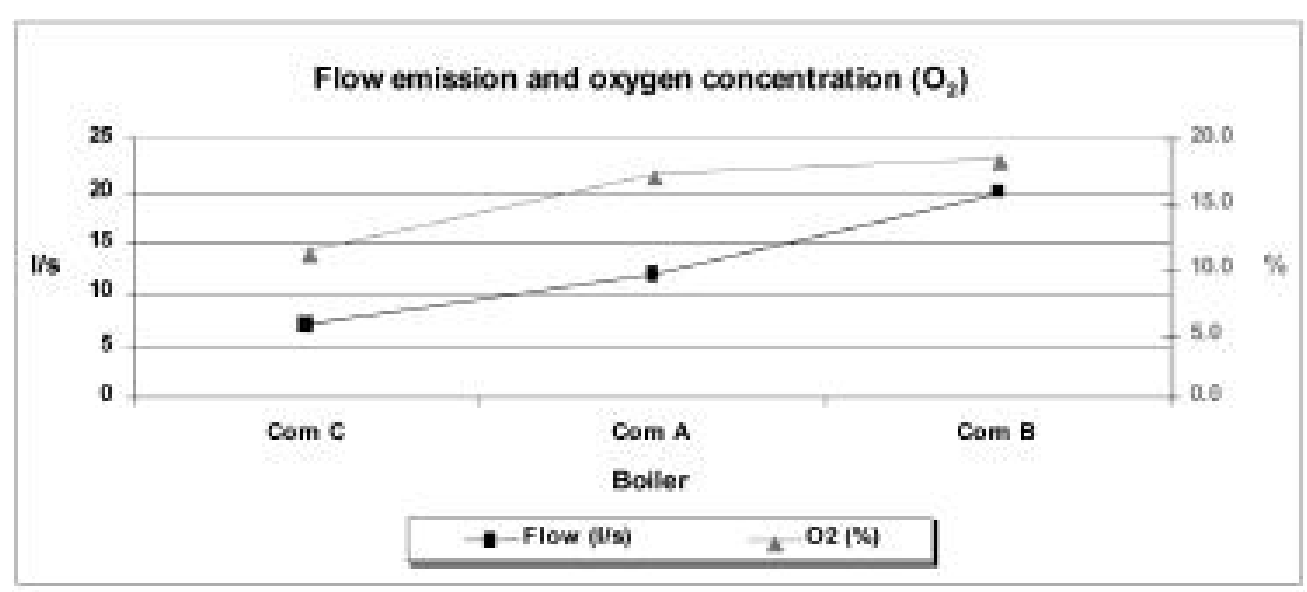

Fig. 7 - Flow emissions of gases and oxygen concentration in corn combustion.

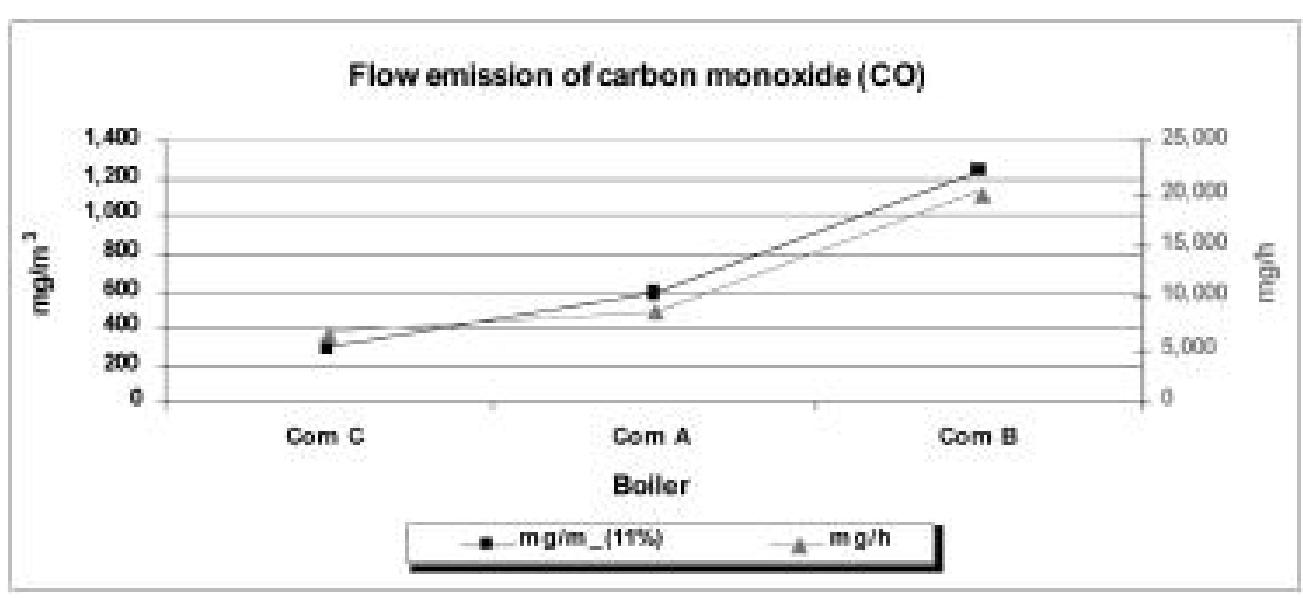

Fig. 8 - Flow emissions of carbon monoxide in corn combustion. 


\subsection{Flow emissions}

The data of flow emissions is expressed in Table 5 for the different corn combustion boilers. The data prove that increasing the content of air in the smoke increases the flow speed (Fig. 7). The results were compared with the values of emission of carbon monoxide and nitrogen oxides expressed in $\mathrm{mg} / \mathrm{m}^{3}$ in adjusting conditions of residual oxygen $(11 \%)$ in the flue gas (Fig 8). The trends of pollutant and flow emissions are similar and highlight the importance of expressing the values in the reference conditions, since in the biomass combustion the excess air is very different.

\section{Conclusions}

This work has wanted to investigate the gaseous emissions from small boilers for domestic heating. In particular, the differences between the emissions of fossil fuels and biomass were investigated.

Data showed a lower emission of pollutants in the flue gas $\left(\mathrm{NO}_{\mathrm{x}}, \mathrm{SO}_{2}\right.$ and $\left.\mathrm{CO}\right)$ by fossil fuel compared to corn in family boilers. This is because fossil fuels are composed of carbon and hydrogen while the biomass composition is very complex.

Moreover, in relation to $\mathrm{CO}$, the emissions of fossil boilers are lower than the biomass, because the fossil fuels are liquid or gaseous and have a better mix with oxygen. Conversely, the solid form of biofuels requires a chop to achieve a good degree of mixing and an incresed temperature in the combustion area. In relation to NOx, biomass emissions are directly proportional to the nitrogen contained in the fuel; higher values for herbaceous biomass and the lowest values for wood biomass. The data also revealed an inverse correlation between carbon monoxide and nitrogen monoxide for corn and barley combustion. Indeed high temperatures in the combustion chamber allows a high NOx formation and a low CO formation. Differently, low temperatures increase the emission of unoxidized compounds but are a limiting factor for the NOx formation.

The mixing of different types of biomass could be useful to improve combustion and therefore emissions into the atmosphere. Thus, for example, mixing maize with wood to form pellets reduces the concentration of nitrogen, with a consequent reduction of the NOx emissions. However, sulphur and carbon emitted by biomass boilers in the local area are a closed loop. These elements are absorbed by plants to produce the same amount of organic matter through the process of photosynthesis.

Most interesting is the strong influence of technological systems to biomass boilers in relation to the reduction of gas emissions into the atmosphere. Corn burners were born from an evolution of pellet boilers and therefore have not developed advanced technology, especially for thermal efficiency and the reduction of emissions into the atmosphere. Conversely, the fos- sil fuel boilers have achieved a very high tecnological maturity, as for example condensing methane boilers. In recent years, biomass boilers are involved in technological progress, which in the near future will allow emission values to be reduced.

In the future we will continue the tests of biomass emissions in a boiler $(25 \mathrm{~kW})$ realized for this purpose. This will allow us to analyze various types of fuel under different operating parameters. In particolar, we want to study the emission of dust and heavy metals into the atmosphere.

\section{References}

Ahmed Khana A., Ahob M., De Jonga W., Vainikkab P., Jansensa P.J., Spliethoffc H., Scale-up study on combustibility and emission formation with two biomass fuels (B quality wood and pepper plant residue) under BFB conditions. Biomass and Bioenergy 32 (2008) 1311-1321.

Bartolelli V., Lazzari M., Impiego energetico delle biomasse vegetali in Italia. Rivista di Ingegneria agraria 4 (2004), 21-28.

Bhattacharya S.C., Abdul Salam P., Mahen Sharma. Emissions from biomass energy use in some selected Asian Countries. Energy 25 (2000) 169-188.

Bignal K.L., Langridge S., John L., Zhou J.L., Release of polycyclic aromatic hydrocarbons, carbon monoxide and particulate matter from biomass combustion in a woodfired boiler under varying boiler conditions. Atmospheric Environment 42 (2008) 8863-8871.

Demirbas A., Potential applications of renewable energy sources, biomass combustion problems in boiler power systems and combustion related environmental issues. Progress in Energy and Combustion Science 31 (2005) 171-192.

ENEA, National Agency for New Technologies, Energy and Environment, Lungotevere Thaon di Revel, 76 00196 - Roma. Environment and energy relationship 2006-2008.

Gubiani R., Lazzari M., Experiences of corn combustion for low quality in a family boiler for low thermal power, full automated. AIIA 2005 "L'ingegneria agraria per lo sviluppo sostenibile dell'area mediterranea”, Catania 27 30 June 2005.

ITABIA, Italian Biomass Association, Via Acireale, 19 00182 - Roma. Report 2008.

Johansson L.S., Leckner B., Gustavsson L., Cooper D., Tullin C., Potter A., Emission characteristics of modern and old-type residential boilers fired with wood logs and wood pellets. Atmospheric Environment 38 (2004) 4183-4195.

Koyuncu T., Pinar Y., The emissions from a space-heating biomass stove. Biomass and Bioenergy 31 (2007) 73-79.

Kristin A., Raymer P., A comparison of avoided greenhouse gas emissions when using different kinds of wood energy. Biomass and Bioenergy 30 (2006) 605-617.

Ndiema C.K.W., Mpendazoe F.M., Williams A., Emission of pollutants from a biomass stove. Energy Conversion Management (1998), 39 (13), 1357-67.

Obernberger I., Brunner T., Barnthaler G., Chemical prop- 
erties of solid biofuels-significance and impact. Biomass and Bioenergy 30 (2006) 973-982.

Olsson M., Kjällstrand J., Emissions from burning of softwood pellets. Biomass and Bioenergy 27 (2004) 607611.

Paul K.I., Booth T.H., Elliott A., Kirschbaum M.U.F., Jovanovic T., Polglase P.J., Net carbon dioxide emissions from alternative firewood-production systems in Australia. Biomass and Bioenergy 30 (2006) 638-647.

Smith KR., Health, energy, and greenhouse-gas impacts of biomass combustion in household stoves. Energy for Sustainable Development 1994;1(4): 23-9.

Teixeira F.N., Lora E.S. Experimental and analytical evaluation of NOx emissions in bagasse boilers. Biomass and Bioenergy 26 (2004) 571-577.

Wahlund B., Yan J., Westermark M., Increasing biomass utilisation in energy systems: A comparative study of $\mathrm{CO}_{2}$ reduction and cost for different bioenergy processing options. Biomass and Bioenergy 26 (2004) 531-544.

Zhang H., Ye X., Cheng T., Chen J.*, Yang X., Wang L., Zhang R., A laboratory study of agricultural crop residue combustion in China: Emission factors and emission inventory. Atmospheric Environment 42 (2008) 8432-8441.

Zhao W., Li Z., Wang D., Zhu Q., Sun R., Meng B., Zhao G., Combustion characteristics of different parts of corn straw and NO formation in a fixed bed. Bioresource Technology 99 (2008) 2956-2963.

Zhou H., Jensen A.D., Glarborg P., Kavaliauskas A., Formation and reduction of nitric oxide in fixed-bed combustion of straw. Fuel 85 (2006) 705-716.

\section{SUMMARY}

The importance of emission control has increased sharply due to the increased need of energy from combustion. However, biomass utilization in energy production is not free from problems because of physical and chemical characteristics which are substantially different from conventional energy sources. In this situation, the quantity and quality of emissions as well as used renewable sources as wood or corn grain are often unknown. To assess this problem the paper addresses the objectives to quantify the amount of greenhouse gases during the combustion of corn as compared to the emissions in fossil combustion (natural gas, LPG and diesel boiler).

The test was carried out in Friuli Venezia Giulia in 2006-2008 to determine the air pollution (CO, NO, $\mathrm{NO}_{2}, \mathrm{NOx}, \mathrm{SO}_{2}$ and $\mathrm{CO}_{2}$ ) from fuel combustion in family boilers with a power between $20-30 \mathrm{kWt}$. The flue gas emission was measured with a professional semi-continuous multi-gas analyzer, (Vario plus industrial, MRU air Neckarsulm-Obereisesheim).

Data showed a lower emission of fossil fuel compared to corn in family boilers in reference to pollutants in the flue gas (NOx, $\mathrm{SO}_{2}$ and $\mathrm{CO}$ ). In a particular way the biomass combustion makes a higher concentration of carbon monoxide (for an incomplete combustion because there is not a good mixing between fuel and air) and nitrogen oxides (in relation at a higher content of nitrogen in herbaceous biomass in comparison to another fuel).

Keywords: Corn, biomass, fossil fuel, boiler, greenhouse emissions, carbon monoxide, carbon dioxide, nitrogen oxide, sulphur dioxide.

\section{Symbols list}

$G C V \quad$ Gross calorific value $(\mathrm{MJ} / \mathrm{kg})$

$N C V \quad$ Net calorific value $(\mathrm{MJ} / \mathrm{kg})$

$w t \% \quad$ Percentage in weight

d.b. Dry basis

w.b. Wet basis

ppm Part per million

$P M \quad$ Molecular weight

$h \quad$ Hour 
006_Antonia(570)_37 1-03-2011 14:57 Pagina 47

$\phi$ 
006_Antonia(570)_37 1-03-2011 14:57 Pagina 48

$\phi$ 